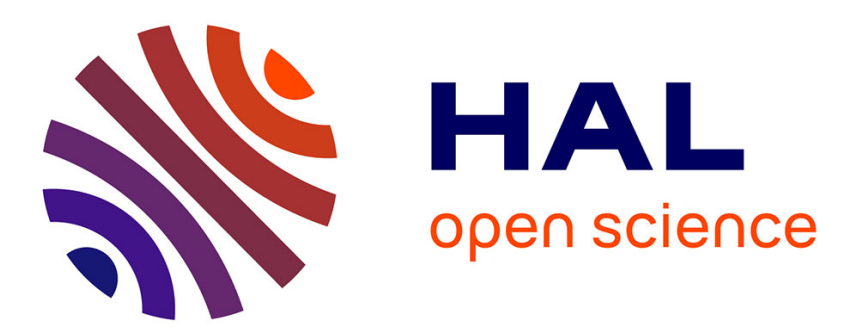

\title{
Does the SWEPOP (Swedish Pregnancy, Obesity and Pelvic Floor) study suffer from a selection bias?
}

\author{
Xavier Fritel, Arnaud Fauconnier
}

\section{To cite this version:}

Xavier Fritel, Arnaud Fauconnier. Does the SWEPOP (Swedish Pregnancy, Obesity and Pelvic Floor) study suffer from a selection bias?. BJOG: An International Journal of Obstetrics and Gynaecology, 2013, 120 (12), pp.1578-9. 10.1111/1471-0528.12417 . inserm-00908220

\section{HAL Id: inserm-00908220 https://www.hal.inserm.fr/inserm-00908220}

Submitted on 22 Nov 2013

HAL is a multi-disciplinary open access archive for the deposit and dissemination of scientific research documents, whether they are published or not. The documents may come from teaching and research institutions in France or abroad, or from public or private research centers.
L'archive ouverte pluridisciplinaire HAL, est destinée au dépôt et à la diffusion de documents scientifiques de niveau recherche, publiés ou non, émanant des établissements d'enseignement et de recherche français ou étrangers, des laboratoires publics ou privés. 


\section{$\underline{\text { Title }}$}

Does the SWEPOP (Swedish Pregnancy, Obesity and Pelvic Floor) study suffer from a selection bias?

\section{$\underline{\text { Text }}$}

Gyhagen et al. have reported a prevalence of urinary incontinence (UI) 20 years after the first birth that is higher in cases of vaginal delivery (40\%) than in cesarean delivery (29\%). They conclude that it would be necessary to achieve 8-9 caesarean sections in order to avoid one case of UI, thereby suggesting that cesarean section has a protective effect $(1,2)$.

This conclusion seems imprudent because a number of preconditions have not been met. A prophylactic intervention should ideally occur before disease onset. UI is particularly common in late pregnancy, when it affects $30-50 \%$ of nulliparous women (3). In reports from the SWEPOP study the UI starting date was not specified, probably because it is not known $(1,2)$. We therefore have no precise idea of the antenatal prevalence of UI in the group of women delivered vaginally as compared with the caesarean group, or whether prevalence was similar in both groups.

The apparent protective effect of cesarean section in this survey could be explained by a selection bias. Two studies have shown that nulliparous women whose pregnancy will end by a cesarean section have prenatal characteristics putting them at a reduced risk of UI such as lower urethral mobility or levator hiatus $(4,5)$. The mode of delivery could quite possibly be a consequence of antenatal pelvic floor characteristics. Urethral mobility measured during pregnancy is predictive of postnatal UI (3). Cesarean delivery at first birth could be an indicator of low UI risk without being really protective. In the current state of knowledge, this alternative explanation is not refutable. Only a randomized trial could answer the question. 
The available randomized trial focusing on breech presentation at term is negative with respect to stress UI prevention.

The absence of a pathophysiological mechanism to explain a causal link between vaginal delivery and UI is also to be considered. The main mechanism of stress UI seems to be intrinsic sphincter deficiency and not urethral mobility (6). Postnatal values of maximum urethral pressure or sphincter volume are similar in cases of vaginal and of cesarean delivery $(3,4)$. Six months after vaginal birth, the values of urethral mobility are similar to the prenatal values (4).

In the latest analysis by Gyhagen et al., it is disturbing to note that the distributions of UI type, severity, and bothersomeness are similar in incontinent women regardless of delivery mode (1). A protective effect of cesarean section would have to be accompanied by a different distribution, with more stress UI, more severe UI, and more bothersome UI in the vaginal delivery group. Instead the authors observed $12.4 \%$ of severe stress UI and $18.1 \%$ of troublesome stress UI in the vaginal delivery group versus $13.7 \%$ and $17.7 \%$ respectively in the caesarean section group.

In conclusion, a selection bias cannot be excluded and we need to be careful not to promote a prophylactic cesarean of which the expected benefits remain unclear.

Xavier FRITEL. Poitiers University Hospital, INSERM CIC802, Poitiers, France.

Arnaud FAUCONNIER. Poissy-Saint-Germain Hospital, EA 7785, Versailles-Saint-Quentin University, Poissy, France.

\section{$\underline{\text { References }}$}

1 Gyhagen M, Bullarbo M, Nielsen TF, Milsom I. A comparison of the long-term consequences of vaginal delivery versus caesarean section on the prevalence, severity and bothersomeness of urinary incontinence subtypes: a national cohort study in primiparous women. BJOG 2013;120(12):1548-55. 
2 Gyhagen M, Bullarbo M, Nielsen TF, Milsom I. Prevalence and risk factors for pelvic organ prolapse 20 years after childbirth: a national cohort study in singleton primiparae after vaginal or caesarean delivery. BJOG 2013;120:152-60.

3 Fritel X, Ringa V, Quiboeuf E, Fauconnier A. Female urinary incontinence, from pregnancy to menopause, a review of epidemiologic and pathophysiologic findings. Acta Obstet Gynecol Scand 2012;91:901-10.

4 Toozs-Hobson P, Balmforth J, Cardozo L, Khullar V, Athanasiou S. The effect of mode of delivery on pelvic floor functional anatomy. Int Urogynecol J Pelvic Floor Dysfunct. 2008;19:407-16

5 Dietz HP, Moore KH, Steensma AB. Antenatal pelvic organ mobility is associated with delivery mode. Aus N Z J Obstet Gynaecol. 2003;43:70-4

6 DeLancey JOL. Why do women have stress urinary incontinence? Neurourol Urodyn. 2010;29:S13-7 